\title{
Hubungan Pengetahuan dan Sikap Terhadap Rokok Dengan Kebiasaan Merokok Siswa SMP di Kota Padang
}

\author{
Afdol Rahmadi*, Yuniar Lestari**, Yenita***
}

\begin{abstract}
Abstrak
Latar belakang: Kota Padang, lebih dari 50\% anak berumur di bawah 18 tahun memulai kebiasaan merokok sebelum usia 13 tahun. Faktor yang dapat mempengaruhi perilaku adalah pengetahuan, sikap, kepercayaan, keyakinan, tradisi, dan nilai. Penelitian ini bertujuan mengetahui hubungan pengetahuan dan sikap terhadap rokok dengan kebiasaan merokok pada siswa SMP di Kota Padang. Metode: jenis penelitian ini adalah analitik observasional dalam bentuk rancangan cross-sectional study. Populasi dalam penelitian ini adalah seluruh siswa SMP di Kota Padang Tahun Ajaran 2011/2012. Jumlah sampel sebanyak 96 siswa yang diambil secara Cluster Sampling dan Simple Random Sampling. Data dikumpulkan dengan angket. Pengolahan data dilakukan secara komputerisasi dan analisis dengan uji Chi-Square pada $\alpha=0,05$. Hasil: didapatkan 32,30\% siswa adalah perokok, 10,4\% dengan pengetahuan rendah, dan $7,3 \%$ dengan sikap negatif. Tidak terdapat hubungan yang bermakna antara pengetahuan $(p=1,000)$ dan sikap $(1,000)$ dengan kebiasaan merokok pada siswa SMP di Kota Padang. Kesimpulan: tidak terdapat hubungan yang bermakna antara pengetahuan $(p=0,155)$ dengan sikap terhadap rokok pada siswa SMP di Kota Padang. Sebaiknya perlu dilakukan penyuluhan kepada siswa SMP di Kota Padang mengenai zat-zat kimia dalam rokok dan asap rokok serta dampaknya terhadap kesehatan.
\end{abstract}

Kata kunci: pengetahuan, sikap, kebiasaan merokok

\begin{abstract}
Background: In Padang, more than 50\% of children aged below 18 years started smoking before the age of 13 . Factors which can influence behavior are knowledge, attitude, belief, conviction, tradition, and value. The purpose of this study was to determine the relationship of knowledge and attitude towards smoking with smoking habit in junior high school students in Padang. Methods: Type of this study was observational analytic, in the form of a crosssectional study. The population in this study is all junior high school students in Padang School Year 2011/2012. The number of samples is as many as 96 students, which was taken by sampling technique namely Cluster Sampling and Simple Random Sampling. Data were collected by questionnaire. Computerized data processing and analysis performed by Chi-Square test at $\alpha=0.05$. Result: obtained $32.30 \%$ of students were smokers, $10.4 \%$ with low knowledge, and $7.3 \%$ with negative attitude. There was no significant relationship between knowledge $(p=1,000)$ and attitude $(p=1,000)$ with smoking habit in junior high school students in Padang. Concultion: there was also no significant relationship between knowledge $(p=0,155)$ and attitude towards smoking in junior high school students in the city of Padang. It is necessary to give counseling to junior high school students in Padang about the chemicals contained in cigarettes, its smoke, and its impact to health.

Keywords : knowledge, attitude, smoking habit
\end{abstract}

Affiliasi penulis : *Fakultas Kedokteran Universitas Andalas, **Bagian Ilmu Kesehatan Masyarakat, ${ }^{* * *}$ Bagian Patologi Anatomi FK.Unand

Korespondensi : Afdol Rahmadi, Fakultas Kedokteran Universitas Andalas afdolrahmadi@gmail.com Telp: 081276506866

\section{PENDAHULUAN}

Sekitar 1 milyar laki-laki di dunia adalah perokok, 35\% diantaranya dari negara maju dan 50\% lainnya dari negara berkembang. Rata-rata 435.000 penduduk di Amerika Serikat meninggal akibat penyakit-penyakit terkait kebiasaan merokok tiap tahunnya, menyebabkan 1 dari 5 kematian.

Berdasarkan data The Asean Tobacco Control Report Card tahun 2008, sebanyak $30,1 \%$ penduduk Asia Tenggara adalah perokok. Di Indonesia sebanyak 57.563.866 penduduk dewasa adalah perokok, menjadikan sebagai negara konsumen rokok tertinggi kelima di dunia. ${ }^{2,3}$

Berdasarkan hasil Riset Kesehatan Dasar (Riskesdas) pada tahun 2010, sebagian besar perokok mulai merokok ketika mereka masih anak-anak atau remaja. Remaja usia Sekolah Menengah Pertama (SMP) di Indonesia didapatkan data pernah merokok sekitar 34\%.,
Tahun 2007 persentase perokok di provinsi Sumatera Barat yang memulai kebiasaan merokok di usia 10-14 tahun sebesar 13,6\%. Angka ini mengalami peningkatan pada tahun 2010 menjadi sebesar $27,7 \%$. Dari uraian tersebut dapat dilihat adanya peningkatan dari kebiasaan merokok pada usia 10-14 tahun, yang mana pada usia tersebut umumnya adalah usia remaja saat duduk dibangku SMP. Menurut data Riset Kesehatan Dasar Provinsi Sumatera Barat Tahun 2007, di kota Padang presentase usia mulai merokok tiap hari pada umur $10-14$ tahun sebesar $6,0 \%{ }^{10,11,28}$

Sebatang rokok mengandung 4000 jenis zat kimia yang 60 zat diantaranya bersifat karsinogenik dan adiktif. Merokok merupakan faktor risiko utama penyakit paru obstruktif kronik dan meningkatkan risiko aterosklerosis. ${ }^{8,9}$

Banyak orang telah mengetahui secara umum bahwa penggunaan tembakau berbahaya bagi kesehatan mereka, namun banyak aspek dari penggunaan tembakau yang belum cukup dijelaskan, sehingga tidak dimengerti dengan baik oleh kebanyakan pengguna tembakau. Akibatnya, perokok cenderung menyepelekan risiko kesehatan dari penggunaan tembakau terhadap diri mereka sendiri dan orang-orang di sekitarnya yang terpapar asapnya. ${ }^{10}$ 
Kebiasaan rokok dimulai dengan adanya rokok pertama. Kebiasaan merokok pada remaja dipengaruhi oleh orang tua, teman sebaya, kepribadian dan media informasi yang mengiklankan rokok. Menurut Green, perilaku seseorang dipengaruhi oleh faktor pendahulu (predisposing) yang meliputi pengetahuan, sikap, kepercayaan, keyakinan, nilai dan tradisi. Pada survei pendahuluan yang dilakukan terhadap 20 orang siswa SMP, diperoleh data 17 orang $(85,0 \%)$ di antaranya pernah merokok dan umumnya mereka mempunyai pengetahuan yang kurang tentang efek negatif dari rokok terhadap kesehatan. ${ }^{11,12,13}$

Penelitian ini dilakukan dengan tujuan untuk mengetahui hubungan pengetahuan dan sikap terhadap rokok dengan kebiasaan merokok siswa SMP di Kota Padang.

\section{METODE}

Jenis penelitian ini adalah analitik observasional dengan pendekatan cross-sectional study. Penelitian dilakukan pada siswa SMP di kota Padang, dilaksanakan pada bulan Januari 2012- Juli 2012.

Sampel pada penelitian ini adalah siswa pada SMP yang terpilih. Sampel yang terpilih pada penelitian ini berjumlah 96 orang. Peneliti menggunakan teknik Cluster Sampling dengan menggelompokkan kecamatan di Kota Padang berdasarkan letaknya yang dekat dengan pusat kota dan yang jauh dari pusat kota. Dari masing-masing kategori terpilih 2 kecamatan secara acak dan dari masing-masing kecamatan tersebut terpilih satu SMP yaitu SMP N 14 Padang, SMP N 17 Padang, SMP N 25 Padang, dan SMP N 29 Padang. Dari masing-masing SMP tersebut dipilih sampel secara simple random sampling pada siswa di setiap tingkatan kelas. Perhitungan jumlah sampel dihitung secara proporsional pada keempat sekolah dan pada setiap tingkatan kelas. Variabel bebas pada penelitian ini adalah pengetahuan dan sikap terhadap rokok. Sedangkan, variabel terikat adalah kebiasaan merokok. Penelitian ini, instrumen yang digunakan adalah angket disertai petunjuk pengisian yang diedarkan kepada responden.

\section{HASIL DAN PEMBAHASAN}

Tabel 1. Distribusi frekuensi kebiasaan merokok siswa SMP di Kota Padang tahun 2012

\begin{tabular}{lll}
\hline $\begin{array}{l}\text { Kebiasaan } \\
\text { Merokok }\end{array}$ & $\mathbf{f}$ & $\%$ \\
\hline Perokok & 31 & 32,3 \\
\hline Bukan Perokok & 65 & 67,7 \\
\hline Jumlah & 96 & 100,0 \\
\hline
\end{tabular}

Tabel 1 menunjukkan sekitar $32,3 \%$ siswa pada SMP di Kota Padang tahun 2012 adalah perokok.

Tabel 2. Distribusi frekuensi pengetahuan siswa tentang rokok pada SMP di Kota Padang tahun 2012

\begin{tabular}{lll}
\hline Pengetahuan & $\mathbf{f}$ & $\%$ \\
\hline Rendah & 10 & 10,4 \\
\hline Tinggi & 86 & 89,6 \\
\hline Jumlah & 96 & 100,0 \\
\hline
\end{tabular}

Tabel 2 menunjukkan sebagian kecil (10,4\%) siswa pada SMP di Kota Padang memiliki pengetahuan yang rendah terhadap rokok.

Tabel 3. Distribusi frekuensi sikap siswa terhadap rokok pada SMP di Kota Padang tahun 2012

\begin{tabular}{lll}
\hline Sikap & f & $\%$ \\
\hline Negatif & 7 & 7,3 \\
\hline Positif & 89 & 92,7 \\
\hline Jumlah & 96 & 100,0 \\
\hline
\end{tabular}

Tabel 3 menunjukkan sebagian kecil (7,3\%) siswa pada SMP di Kota Padang memiliki sikap negatif terhadap rokok.

Tabel 4. Hubungan pengetahuan tentang rokok dengan kebiasaan merokok siswa pada SMP di Kota Padang tahun 2012

\begin{tabular}{|c|c|c|c|c|c|c|c|}
\hline \multirow{3}{*}{$\begin{array}{l}\text { Penget } \\
\text { ahuan }\end{array}$} & \multicolumn{4}{|c|}{ Kebiasaan Merokok } & \multirow{2}{*}{\multicolumn{2}{|c|}{ Jumlah }} & \multirow[b]{2}{*}{$\begin{array}{l}\text { P } \\
\text { Value }\end{array}$} \\
\hline & \multicolumn{2}{|c|}{ Perokok } & \multicolumn{2}{|c|}{$\begin{array}{l}\text { Bukan } \\
\text { Perokok }\end{array}$} & & & \\
\hline & $f$ & $\%$ & $f$ & $\%$ & $f$ & $\%$ & \\
\hline Rendah & 3 & 30,0 & 7 & 70,0 & 10 & 100,0 & \\
\hline Tinggi & 28 & 32,6 & 58 & 67,4 & 86 & 100,0 & \\
\hline Jumlah & 31 & 32,3 & 65 & 67,7 & 96 & 100,0 & \\
\hline
\end{tabular}

Tabel 4 menunjukkan persentase siswa yang merokok lebih tinggi pada tingkat pengetahuan tinggi $(32,6 \%)$ dibandingkan pada tingkat pengetahuan rendah (30\%)

Tabel 5. Hubungan sikap terhadap rokok dengan kebiasaan merokok siswa pada SMP di Kota Padang tahun 2012

\begin{tabular}{|c|c|c|c|c|c|c|c|}
\hline \multirow{3}{*}{ Sikap } & \multicolumn{4}{|c|}{ Kebiasaan Merokok } & \multirow{2}{*}{\multicolumn{2}{|c|}{ Jumlah }} & \multirow{3}{*}{$\begin{array}{l}\mathbf{P} \\
\text { Value }\end{array}$} \\
\hline & \multicolumn{2}{|c|}{ Perokok } & \multicolumn{2}{|c|}{$\begin{array}{l}\text { Bukan } \\
\text { Perokok }\end{array}$} & & & \\
\hline & $f$ & $\%$ & $f$ & $\%$ & $f$ & $\%$ & \\
\hline Negatif & 2 & 28,6 & 5 & 71,4 & 7 & 100,0 & \\
\hline Positif & 29 & 32,6 & 60 & 67,4 & 89 & 100,0 & \\
\hline Jumlah & 31 & 32,3 & 65 & 67,7 & 96 & 100,0 & 1,000 \\
\hline
\end{tabular}

Tabel 5 menunjukkan persentase siswa yang merokok lebih tinggi pada sikap positif $(32,6 \%)$ dibandingkan pada sikap negatif $(28,6 \%)$.

Tabel 6. Hubungan pengetahuan tentang rokok dengan sikap siswa terhadap rokok pada SMP di Kota Padang tahun 2012

\begin{tabular}{llllllll}
\hline \multirow{2}{*}{$\begin{array}{l}\text { Penget } \\
\text { ahuan }\end{array}$} & \multicolumn{2}{l}{ Sikap } & \multicolumn{2}{l}{ Jumlah } & P \\
\cline { 2 - 7 } & \multicolumn{2}{l}{ Negatif } & \multicolumn{2}{l}{ Positif } & & & Value \\
\cline { 2 - 7 } & $\mathrm{f}$ & $\%$ & $\mathrm{f}$ & $\%$ & $\mathrm{f}$ & $\%$ & \\
\hline Rendah & 2 & 20,0 & 8 & 80,0 & 10 & 100,0 & \\
\hline Tinggi & 5 & 5,8 & 81 & 94,2 & 86 & 100,0 & \multirow{2}{*}{0,155} \\
\hline Jumlah & 7 & 7,3 & 89 & 92,7 & 96 & 100,0 & \\
\hline
\end{tabular}

Tabel 6 menunjukkan persentase siswa dengan sikap negatif lebih tinggi pada pengetahuan rendah $(20 \%)$ dibandingkan pada pengetahuan tinggi $(5,8 \%)$.

Hasil penelitian ini, didapatkan $32,3 \%$ siswa adalah perokok. Hasil penelitian ini menunjuk-kan hasil yang berbeda dengan penelitian yang di-lakukan oleh Andayani AH (2003) pada sejumlah siswa SLTP 
Negeri di Bekasi yang memperoleh hasil 48\% siswa merupakan perokok. Perbedaan angka prevalensi ini dapat terjadi karena waktu dan populasi penelitian yang berbeda. ${ }^{14}$

Berdasarkan observasi yang dilakukan pada masing-masing SMP mempunyai peraturan larangan merokok bagi siswa dan berjualan rokok bagi kantinkantin di dalam sekolah, namun siswa masih dapat memperoleh rokok di warung sekitar sekolah. Di masing-masing SMP didapatkan banyaknya poster yang menghimbau untuk tidak merokok dan tentang efek negatif rokok terhadap kesehatan, tetapi masih ada guru dan pegawai yang merokok di lingkungan sekolah bahkan di hadapan siswa. Hal-hal tersebut memungkinkan siswa untuk merokok.

Dari hasil penelitian didapatkan hampir seluruh siswa $(89,6 \%)$ memiliki pengetahuan yang baik tentang rokok. Hasil penelitian ini berbeda dengan hasil penelitian Sabri FP (2007) pada 293 orang siswa SMA laki-laki di Kecamatan Bangkinang Kabupaten Kampar dimana didapatkan tingkat pengetahuan tinggi sebanyak $46,1 \%$. Perbedaan hasil ini dapat terjadi karena perbedaan populasi dan letak geografis. Responden yang berdomisili di kota lebih mudah mendapatkan informasi sehingga memiliki pengetahuan yang lebih tinggi. ${ }^{15}$

Pengetahuan yang banyak tidak diketahui oleh siswa, diantaranya adalah gas yang terdapat dalam asap rokok yang mampu berikatan dengan hemoglobin darah $(97,9 \%)$, bahaya asap rokok terhadap perokok aktif dan pasif $(69,8 \%)$ dan zat racun yang terdapat dalam rokok $(65,6 \%)$. Kurangnya pengetahuan siswa mengenai hal tersebut disebabkan oleh karena siswa SMP belum memperoleh pengetahuan yang dalam mengenai zat-zat kimia yang terkandung dalam rokok dan mekanismenya dalam menimbulkan dampak negatif terhadap tubuh.

Dari hasil penelitian didapatkan pada umumnya siswa $(92,7 \%)$ mempunyai sikap yang positif terhadap kebiasan merokok. Hasil ini sama dengan penelitian yang dilakukan oleh Ulvia (2011) di Kota Padang yang mendapatkan $90,8 \%$ siswa dengan sikap positif terhadap kebiasaan merokok. ${ }^{7}$

Secara keseluruhan siswa setuju bahwa kebiasaan merokok adalah tindakan yang negatif, tetapi ada siswa yang mempunyai sikap negatif terhadap kebiasaan merokok yaitu $7,3 \%$. Dari hasil yang didapatkan, terlihat bahwa ada sebagian siswa yang cenderung ingin diberi kebebasan untuk merokok. Hal ini sesuai dengan teori Richmond dan Sklansky dalam Sarwono SW (2011) yang mengatakan bahwa inti dari tugas perkembangan seseorang dalam periode remaja awal dan menengah adalah memperjuangkan kebebasan. Dalam hal ini, siswa SMP menginginkan guru memberikan mereka kebebasan untuk merokok di lingkungan sekolah. ${ }^{16}$

Hasil penelitian didapatkan proporsi siswa yang merokok lebih besar pada siswa dengan pengetahuan tinggi dibandingkan pengetahuan rendah (32,6\%:30\%). Secara statistik tidak terdapat hubungan yang bermakna antara pengetahuan terhadap rokok dengan kebiasaan merokok $(p=1,000)$. Hal ini kemungkinan disebabkan oleh masih banyaknya perokok yang tidak peduli dengan risiko kebiasaan merokok terhadap kesehatan miskipun sudah mengetahuinya. Banyak perokok telah mengetahui secara umum bahwa penggunaan tembakau berbahaya bagi kesehatan mereka tetapi perokok cenderung menyepelekan risiko terhadap diri mereka sendiri dan orang-orang di sekitarnya yang terpapar asap rokok. ${ }^{10}$

Penelitian ini menunjukkan hasil yang berbeda dengan penelitian Sabri (2007) pada siswa lakilaki di SMA Kecamatan Bangkinang Kabupaten Kampar, yang menyatakan bahwa terdapat hubungan yang bermakna antara tingkat pengetahuan dengan kebiasaan merokok $(p=0,003)$. Begitu juga dengan hasil penelitian Kurniasih (2008) pada siswa SLTP di Kota Bekasi menyatakan adanya hubungan antara tingkat pengetahuan dengan kebiasaan merokok. ${ }^{15,17}$

Menurut Kurt Lewin dalam Komalasari dan Helmi (2008), kebiasaan merokok selain di-pengaruhi oleh faktor dari dalam diri seseorang, misalnya pengetahuan, juga dipengaruhi oleh faktor lingkungan. Faktor lingkungan bisa saja dari faktor keluarga, tempat tinggal atau bahkan lingkungan per-gaulan. Seperti yang disampaikan oleh Daravill dan Powell (2002) bahwa remaja cenderung merokok karena memiliki teman-teman atau keluarga yang merokok. ${ }^{18,19}$

Dari hasil penelitian ini didapatkan proporsi siswa yang merokok lebih tinggi dengan sikap positif daripada sikap negatif $(32,6 \%: 28,6 \%)$. Hasil uji statistik menunjukkan tidak terdapat hubungan yang bermakna antara sikap dengan kebiasaan merokok $(p=1,000)$. Hal ini kemungkinan disebabkan oleh karena ada faktor lain yang dapat mempengaruhi kebiasaan merokok.

Kebiasaan merokok pada remaja dipengaruhi oleh orang tua, teman sebaya, kepribadian dan media informasi yang mengiklankan rokok. Menurut Berry dalam Oktavia (2010), teman sebaya mempunyai peran yang sangat berarti bagi remaja, karena remaja lebih sering menghabiskan waktunya bersama temanteman sebaya. Di antara remaja yang memiliki kebiasaan merokok, $87 \%$ diantaranya mempunyai sekurang-kurangnya satu atau lebih sahabat yang memiliki kebiasaan merokok begitu pula dengan remaja non perokok. ${ }^{12,20}$

Hasil ini berbeda dengan penelitan Hasan (2005) pada pelajar SMP di Surakarta menunjukkan adanya hubungan sikap dengan perilaku merokok dan penelitian Noor (2004) pada siswa SMP Kudus menyatakan adanya hubungan sikap dengan perilaku merokok. ${ }^{21,22}$

Penelitian didapatkan proporsi siswa dengan pengetahuan rendah mempunyai sikap negatif lebih tinggi (20\%) dibandingkan siswa yang mempunyai sikap negatif dengan pengetahuan tinggi (5,8\%). Hasil uji statistik menunjukkan tidak adanya hubungan yang bermakna antara pengetahuan ter-hadap rokok dengan sikap terhadap rokok $(p=0,155)$.

Hasil ini kemungkinan disebabkan oleh faktor lain yang dapat mempengaruhi sikap seseorang. Menurut Sumarwan (2003) sikap mempunyai tiga unsur yaitu kognitif (pengetahuan), afektif (emosi, perasaan) dan konaktif (tindakan). Dari unsur emosi atau perasaan, remaja dapat di terpicu untuk bersikap negatif terhadap rokok karena melihat iklan di media massa dan elektronik yang menampilkan gambaran bahwa perokok adalah lambang kejantanan atau glamour walaupun sebenarnya dia mempunyai pengetahuan yang baik tentang rokok, dimana pengetahuan yang tinggi ataupun rendah tidak mempengaruhi seseorang dalam kebiasaan merokok ${ }^{12,23}$ 


\section{KESIMPULAN}

Penelitian ini dapat disimpulkan bahwa pengetahuan siswa SMP di Kota Padang tentang rokok sebagian besar tinggi, sikap terhadap rokok sebagian besar positif. Hampir sepertiga siswa SMP di Kota Padang adalah perokok,, dimana sebagian besar diantaranya adalah perokok ringan. Pengetahuan tentang rokok tidak berhubungan dengan sikap terhadap rokok. Pengetahuan tentang rokok tidak berhubungan dengan kebiasaan merokok, dan sikap terhadap rokok tidak berhubungan dengan kebiasaan merokok.

\section{DAFTAR PUSTAKA}

1. Benowitz, NL. Nicotine Addiction. N Engl J Med, 2010;362:2295-303.

2. Syafiq A. Perilaku Siswa SMP Dharma Pancasila Medan Tentang Merokok. Medan: FK USU. 2010.

3. Departemen Kesehatan Republik Indonesia. Perokok Pasif Mempunyai Risiko Lebih Besar Dibandingkan Perokok Aktif. Direktorat Jendral Kesehatan Masyarakat, Direktorat Promosi Kesehatan. 2004.

4. Departemen Kesehatan Republik Indonesia. Riset Kesehatan Dasar 2010. Badan Pelitian dan Pengembangan Kesehatan. diakses dari : http://www.riskesdas.litbang.depkes.go.id/laporan 2010/reg.php [23 Maret 2012].

5. Aditama, TY. Global Youth Tobacco Survey (Repeat) Indonesia 2004. diakses dari: http://searo.who.int/linkfiles/GYTS_Indonesia_rep eatsurvey.pdf [20 Maret 2012].

6. Departemen Kesehatan Republik Indonesia. Riset Kesehatan Dasar 2007. Badan Penelitian dan Pengembangan Kesehatan. Jakarta: Departemen Kesehatan RI. 2008.

7. Ulvia SN. Faktor-Faktor yang Berhubungan Dengan Perilaku Merokok Siswa Pada Empat SMP Negeri di Kota Padang [Skripsi]. Padang: PSIKM UNAND. 2011.

8. Gondodiputro S. Bahaya Tembakau dan Bentuk Bentuk Sediaan Tembakau. Bagian IImu Kesehatan Masyarakat FK. Unpad diakses dari:http://resources.unpad.ac.id/unpadcontent/ uploads/publikasi_dosen/Rokok.PDF,2007[18 Maret 2012].
9. Jaakkola M.S. Environmental tobacco smoke and health in the elderly. Eur Respir J 2002;19: 172 181.

10. WHO, 2011. Who report on the Global Tobacco Epidemic. WHO.diakses dari: http://whqlibdoc. who.int/publications/2011/9789240687813 eng. pdf [12 Februari 2012].

11. Sarafino FP. Health Psychology (2-nd Edition). New York: John Wiley \& Sons. 1994.

12. Mu'tadin Z, 2002. Remaja dan Rokok. Jakarta : diakses dari http://www.e-psikologi.com/epsi/ individual detail.asp?id=379 [5 Maret 2012].

13. Notoatmodjo S. Pendidikan dan Perilaku Kesehatan. Jakarta: Rineka Cipta. 2003

14. Andayani, AH. Aplikasi Kerangka Green dalam Memahami Perilaku Merokok pada Pelajar Kelas 3 SLTPN 4 Cikarang Utara Bekasi, 2003.

15. Sabri FP. Hubungan Tingkat Pengetahuan Dan Sikap Tentang Merokok Dengan Kebiasaan Merokok Siswa SMA Laki-Laki Di Kecamatan Bangkinang Kabupaten Kampar [Skripsi].Padang : FK UNAND. 2007.

16. Sarwono SW. Psikologi Remaja. Jakarta: Rajawali Pers. 2011.

17. Kurniasih A. Faktor-Faktor yang Berhubungan dengan Perilaku Merokok pada Siswa SLTP di Kota Bekasi tahun 2008.Depok : FKM UI. 2008

18. Komalasari D, Helmi AF. Faktor-faktor Penyebab Perilaku Merokok Pada Remaja. Universitas Gadjah Mada Press. diakses dari: http://avin. staff.ugm.ac.id/data/jurnal/perilaku merokok avi n.pdf[15 Maret 2012].

19. Daravill W, Powell K. The Puberty Book (Panduan Untuk Remaja). Jakarta: Gramedia. 2002.

20. Oktavia D, Faktor Internal dan Eksternal yang Berhubungan dengan Tindakan Merokok Siswa Laki-Laki di SMA Negeri Kota Padang Tahun 2010 [Skripsi]. Padang : PSIKM UNAND. 2010.

21. Hasan A. Pengetahuan, Sikap dan Perilaku Merokok Pelajar SMP di Surakarta[Skripsi]. Jakarta: FKUI. 2005

22. Noor F. Faktor-Faktor yang Berpengaruh Terhadap Praktik Merokok pada Remaja Sekolah Menengah Pertama di Kabupaten Kudus [Tesis]. Semarang: FKM UNDIP. 2004.

23. Suwarman U. Perilaku Konsumen: Teori dan Penerapannya dalam Pemasaran. Jakarta : Ghalia Indonesia. 2003. 